\title{
Polycystic hydatidosis and hepatocellular carcinoma
}

\author{
Danielly Moreira Gonçalves ${ }^{1}$, Rita de Cassia Ribeiro Pereira ${ }^{1,2}$, Idila Mont'AlverneXavier de Oliveira ${ }^{1}$, Irenilce Souza de Matos ${ }^{1}$, Rogerio \\ Ferraz Baquette $^{1}$, Rosangela Rodrigues-Silva ${ }^{3}$ and Nilton Ghiotti de Siqueira ${ }^{1,2 *}$ \\ ${ }^{1}$ Acre State Hospital Foundation, Rio Branco, Estado do Acre, Brazil \\ ${ }^{2}$ Federal University of Acre, Medical School, Rio Branco, Estado do Acre, Brazil \\ ${ }^{3}$ Laboratory of Helminth Parasites of Vertebrates, Osvaldo Cruz Foundation, Rio de Janeiro, Brazil
}

\begin{abstract}
Polycystic hydatidosis (Neotropical echinococcosis) is a zoonosis, with Echinococcus vogeli acting as the etiological agent. It occurs solely in the New World, with reports of cases coming almost exclusively from the Amazon region. This condition has a chronic evolution, the symptoms of which only manifest in the most advanced stage of the disease with symptoms of palpable abdominal mass. The organ most frequently affected is typically the liver. Hepatocellular Carcinoma (HCC) is prevalent in more than 1.5 million people worldwide. In Brazil, Hepatocellular Carcinoma is related to Hepatitis B and C viral infections in $68.5 \%$ of cases. The hepatitis incidence in the Amazon region is higher than in other regions of the country and is one of the differential diagnoses of polycystic hydatidosis. The concomitance of these infections has not yet been described in the literature.
\end{abstract}

\section{Introduction}

Polycystic Hydatidosis (Neotropical echinococcosis) is a zoonosis, with Echinococcus vogeli acting as the etiological agent. It occurs solely in the New World [1,2], with reports of cases coming almost exclusively from the Amazon region. Its biological cycle involves two hosts: the Bush Dog (Speothos venaticus), and rodents, particularly the Lowland Paca (Cuniculus paca). Human beings are affected upon ingesting E. vogeli eggs which are eliminated along with the feces of domestic dogs. The dogs are infected when, during hunting, they are fed viscera contaminated with the larval form of E. vogeli [3-5]. This condition has a chronic evolution, the symptoms of which only manifest in the most advanced stage of the disease with symptoms of palpable abdominal mass. The organ most frequently affected is typically the liver. Other organs that may be involved include the diaphragm, spleen, pancreas, omentum, mesentery and uterus $[3,6,7]$.

Hepatocellular Carcinoma (HCC) is prevalent in more than 1.5 million people worldwide, with approximately 20,000 new cases in the United States and Brazil. HCC is the fifth most common malignant neoplasm in men, and the seventh in women. Most patients are found in poorly developed countries, notably in regions in where the Hepatitis B virus is endemic, such as in southern Asia and Sub-Saharan Africa. In Brazil, this affliction affects about 10/100,000 individuals. HCC is rarely found in individuals below the age of 40 , while peaking at approximately 70 years of age. This neoplasia affects the male gender 2 to 4 times than the female [8,9]. In Brazil, Hepatocellular Carcinoma is related to Hepatitis B and C viral infections in $68.5 \%$ of cases. The hepatitis incidence in the Amazon region is higher than in other regions of the country [10].

\section{Case report}

The patient is a 40-year-old male, hailing from Santa Rosa do Purús, AC. The patient was sent to the Gastroenterology Service. He presented epigastric pain over a 3-month period, associated with nausea, heartburn, postprandial fullness and early satiety. He lost
$6 \mathrm{~kg}$ during that period. System Review and Previous Pathological History contained no relevant data. Epidemiological History included the subject's habit of hunting, and his Social History of having dogs present at his place of residence. The physical examination returned with normal results with the exception of the presence of a palpable liver of $4 \mathrm{~cm}$ from the right costal margin, painless and with a smooth surface.

Ultrasound on 4/11/15: Two isoechoic images, rounded and heterogeneous, exhibiting defined limits with posterior acoustic shadow; Solid, and located in Seg. II; Measuring $9 \mathrm{~cm}$ at its greatest, and $3 \mathrm{~cm}$ at its smallest; Absence of intra or extrahepatic dilatation. Computerized tomography on 11/17/15: Liver nodules exhibit neoplastic aspects, with agglomerated and confluent cysts in LD. Serology results for HIV 1 and 2, as well as Hepatitis B and C, negative. Alpha-fetal-protein: $17436 \mathrm{ng} / \mathrm{mL}$. CEA: $4.86 \mathrm{ng} / \mathrm{mL}$. UGIE on 1/15/16: Moderate endoscopic enanthematous Pangastritis. Colonoscopy on 1/18/16: Normal. Thoracic X-ray on 3/13/16: Normal. Other staging exams reveal NX M0.

On 29/01/2016, patient underwent a left hepatectomy and resection of lesion in Seg. VII, as well as alcoholization of 2 nodules, each 1 $\mathrm{cm}$, in Seg. V. The patient was discharged on the $7^{\text {th }}$ postoperative day, without intercurrences. Histopathology: Left lobe - Moderately differentiated Hepatocellular Carcinoma, surgical margins unaffected, intact Glisson's capsule. Cystic lesion: Hydatidosis (Figures 1-3).

*Correspondence to: Nilton Ghiotti de Siqueira, Acre State Hospital Foundation, Rio Branco, Estado do Acre, Brazil, Tel: 55-68-9 92295560; E-mail: nilton ghiotti@uol.com.br

Key words: polycystic hydatidosis; Echinococcus vogeli; hepatocellular carcinoma Received: August 28, 2018; Accepted: September 17, 2018; Published: September 21, 2018 


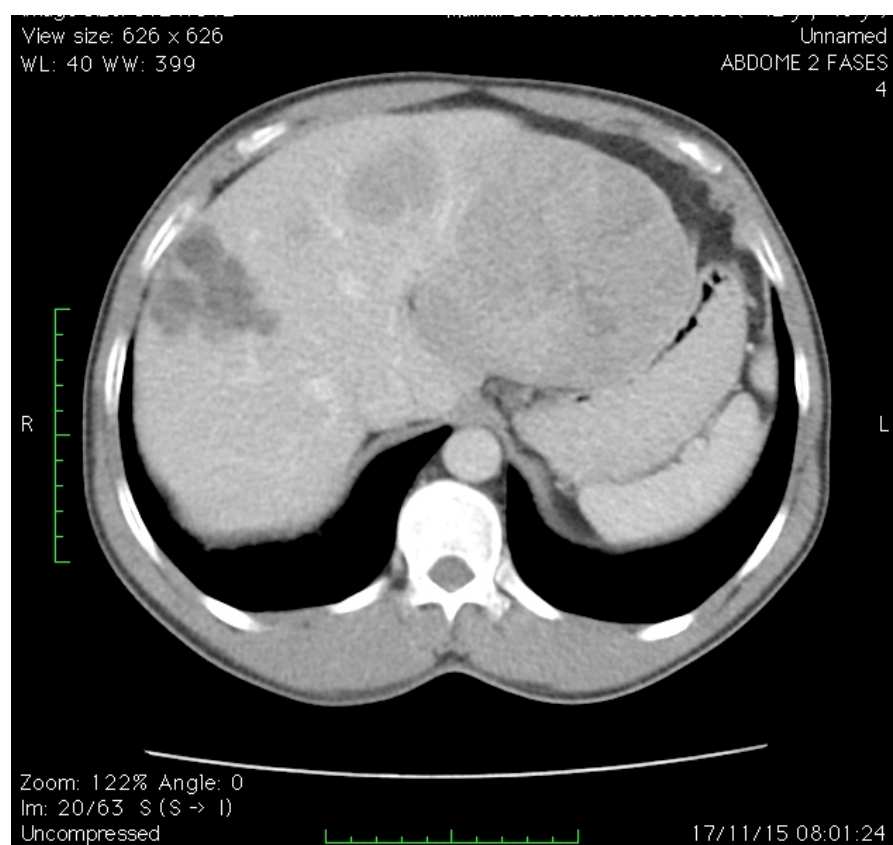

Figure 1. Computerized tomography with contrast, portal phase, voluminous lesion in Segments II and IVa, and cystic lesions grouped in Segment VIII

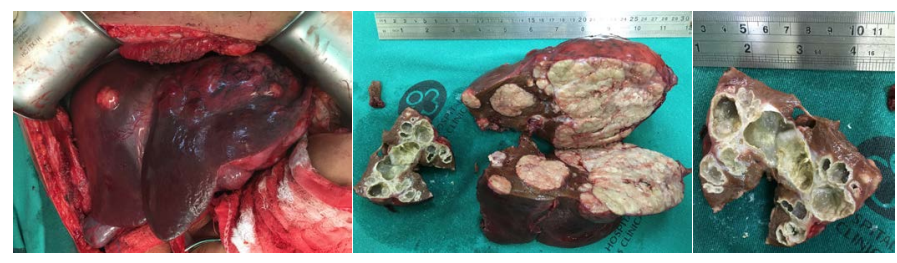

Figure 2. Aspects of the surgery: a) In situ lesions in Segments IVa and II; b) cystic lesions of Segment VII and solid lesions in Segments IVa and II; c) macroscopic aspect of the cystic lesions, observation of vesicles on the interior of the lesions

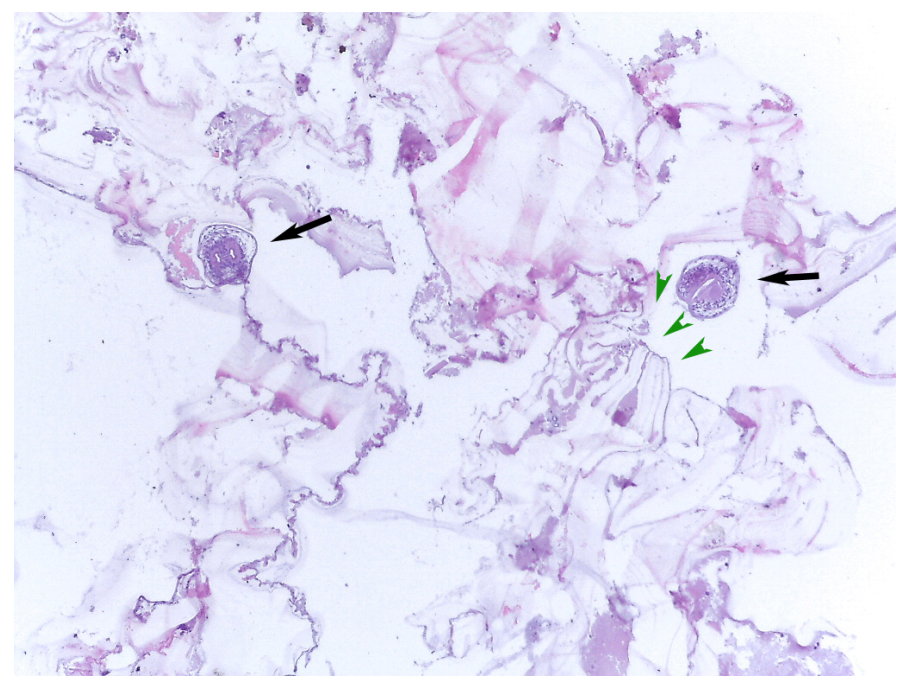

Figure 3. Characteristic histological appearance of the laminated membrane showing a cerebral aspect, one of the characteristics of Echinococcus vogeli (green arrows) and protoscoleces (black arrows) (HE)

\section{Discussion and conclusion}

Hydatidosis is a disease that can manifest as abdominal palpable mass, and cystic lesions are found in infected organs, notably in the liver $[11,12]$. This affliction may mimic neoplastic lesions in affected patients, which may compromise the management of these patients. Said patients are usually treated with chemotherapy (albendazole) and/or surgery. The combination of these forms of treatment is safer and more effective $[7,13]$. Surgical findings are also important for diagnostic confirmation, as well as to rule out neoplasia. The resected cysts must be sent for anatomopathological analysis in order to identify characteristics of the cyst capsules and aculeus which are consistent with E. vogeli infection $[6,14]$.

The findings of cystic lesions with peripheral calcifications in patients with compatible epidemiological history through imaging exams, particularly Computerized Tomography, are also considered as diagnostic criteria for Hydatidosis. Serological tests may also be used for diagnostic evaluation. There are, however, limitations on sensitivity and specificity $[3,12]$.

Imaging methods are important tools in the detection and establishment of a noninvasive diagnosis of HCC, with its diagnosis being possible even without biopsy. Cases of non-classical HCC are confirmed by anatomopathological study [15].

The coexistence of cystic hydatidosis $(\mathrm{CH})$, whose etiologic agent consists of E. granulosus and hepatocellular carcinoma, is a rare event [16-22]. However, there is no mention in the literature of the correlation between HCC and polycystic hydatidosis, the etiological agent of which is E. vogeli. The latter is generally found in the Amazon Region and its frequency is high in populations of the State of Acre [3,23-26].

$\mathrm{CH}$ can manifest as tumor-like, and with lesions in the liver, which have been caused by the parasite; it may be infiltrative in nature, whereas the parasites may reside in their hosts and remain clinically unnoticed for long periods [27]. On the other hand, it is speculated that the metacestode may acquire some means of modulating the human immune response, neutralizing the adverse reactions of the host and, in turn, influencing the physiology of the peri-parasitic area to its own advantage. Similarly, the cancer is also related to changes in the immune system $[27,28]$.

Recently, Stadelmann et al. [29] reported that phosphoglucose isomerase from E. multilocularis (EmPGI), a component of the metacestode laminar layer, showed a similarity in the amino acid sequence of $86 \%$, with that of human PGI. PGI in mammals consists of a multifunctional protein that can act as a cytokine, growth factor and inducer of angiogenesis. This plays a role in tumor development and metastasis. Based on this information, the possibility that echinococcosis may play a role in the development and metastasis of HCC in humans is demonstrated [30].

In the State of Acre, where the case in question occurred, coinfection of polycystic hydatidosis, hepatitis B and C virus, as well as HIV, was identified. However, despite the risk factors for HCC, this patient had exhibited no evidence of primary malignant neoplasm of the liver [31]. In contrast, the subject of this study had no risk factors for HCC and presented this primary neoplasia.

\section{References}

1. Craig PS, McManus DP, Lightowlers MW, Chabalgoity JA, Garcia HH, et al. (2007) Prevention and control of cystic echinococcosis. Lancet Infect Dis 7: 385-394. [Crossref]

2. Tappe D, Stich A, Frosch M (2008) Emergence of polycystic neotropical echinococcosis Emerg Infect Dis 14: 292-297. [Crossref]

3. D'Alessandro A, Rausch RL (2008) New aspects of neotropical polycystic (Echinococcus vogeli) and unicystic (Echinococcus oligarthrus) echinococcosis. Clin Microbiol Rev 21: 380-401. [Crossref] 
4. Jenkins DJ, Romig T, Thompson RC (2005) Emergence/re-emergence of Echinococcus spp.--a global update. Int J Parasitol 35: 1205-1219. [Crossref]

5. do Carmo Pereira Soares M, Souza de Souza AJ, Pinheiro Malheiros A, Nunes HM, Almeida Carneiro L, et al. (2014) Neotropical echinococcosis: second report of Echinococcus vogeli natural infection in its main definitive host, the bush dog (Speothos venaticus). Parasitol Int 63: 485-487. [Crossref]

6. Siqueira NG, Almeida FB, Suzuki YA, Lima RN, Machado-Silva JR, et al. (2010) Atypical polycystic echinococcosis without liver involvement in Brazilian patients. Trans R Soc Trop Med Hyg 104: 230-233.

7. Siqueira NG, de Almeida FB, Chalub SR, Machado-Silva JR, Rodrigues-Silva R (2007) Successful outcome of hepatic polycystic echinococcosis managed with surgery and chemotherapy Trans $R$ Soc Trop Med Hyg 101: 624-626.

8. http://www.inca.gov.br/estimativa/2016/

9. http://www.iarc.fr/

10. Miranda EC, Moia Lde J, Amaral Ido S, Barbosa MS, Conde SR, et al. (2004) Hepatitis $\mathrm{B}$ and $\mathrm{C}$ virus infection and the hepatocellular carcinoma in the East Amazon, Brazil. Rev Soc Bras Med Trop 37: S47-S51. [Crossref]

11. Meneghelli UG, Martinelli AL, Velludo MA (1990) Echinococcus vogeli cysts in paca liver (Cuniculus paca) native from the Acre State, Brazil. Rev Soc Bras Med Trop 23: 153-155. [Crossref]

12. Siqueira NGd, Siqueira CMVMd, Rodrigues-Silva R, Soares MdCP, Póvoa MM (2013) Polycystic echinococcosis in the state of Acre, Brazil: contribution to patient diagnosis, treatment and prognosis. Mem Inst Oswaldo Cruz 108: 533-540.

13. D’Alessandro A (2010) Hidatidosis poliquística tropical por Echinococcus vogeli. Rev Asoc Méd Argent 123: 16-23.

14. Basset D, Girou C, Nozais IP, D'Hermies F, Hoang C, et al. (1998) Neotropical echinococcosis in Suriname: Echinococcus oligarthrus in the orbit and Echinococcus vogeli in the abdomen. Am J Trop Med Hyg 59: 787-90. [Crossref]

15. Purysko AS, Remer EM, Coppa CP, Leao Filho HM, Thupili CR, et al. (2012) LIRADS: a case-based review of the new categorization of liver findings in patients with end-stage liver disease. Radiographics 32: 1977-1995. [Crossref]

16. Karadas S, Dulger AC, Gonullu H, Bulut G, Beyazal M (2014) Coexistence of hepatocelluler carcinoma and cyst hydatid disease of the liver. J Pak Med Assoc 64: 1075-1077. [Crossref]

17. Bourne MS, Williams GE (1963) Compression of the inferior vena cava by hydatid disease of the liver with associated hepatocellular carcinoma. Gastroenterology 45 : 667-669. [Crossref]

18. Hoffmann T, Schlensak M, Erhard J, Trenn G (2003) Echinococcosis - a rare differential diagnosis of a tumorous hepatic lesion. Z Gastroenterol 41: 913-916. [Crossref]
19. Kato T, Seino Y, Takada K, Maruya M, Okubo S, et al. (2003) A resectable case of hepatocellular carcinoma complicated with hepatic alveolar echinococcosis. Nihon Shokakibyo Gakkai Zasshi 100: 587-592. [Crossref]

20. Kostov D, Dragnev N, Patanov R, Kobakov G (2010) Hepatocellular carcinoma complicated with echinococcal cyst of the liver. Khirurgiia (Sofiia): 49-50. [Crossref]

21. Perrone Donnorso R (1969) Double peritoneal dissemination of hydatidosis and concomitant hepatocellular carcinoma. Riv Anat Patol Oncol 35: 266-280. [Crossref]

22. Sygut A, Gorski A, Dziki A (1987) A case of coexistence of primary cancer of the liver and hepatic echinococcosis. Wiad Lek 40: 826-268. [Crossref]

23. Pastore R, Vitali LH, Macedo Vde O, Prata A (2003) A serological survey of the infection by Echinococcus sp. in the municipality of Sena Madureira, AC. Rev Soc Bras Med Trop 36: 473-477. [Crossref]

24. Almeida F, Caldas R, Corrêa C, Rodrigues-Silva R, Siqueira N, et al. (2013) Coinfections of the cestode Echinococcus vogeli and the nematode Calodium hepaticum in the hystricomorphic rodent Agouti paca from a forest reserve in Acre, Brazil. $J$ Helminthol 87: 489-493. [Crossref]

25. Soares MDCP, Moreira-Silva CA, Alves MM, Nunes HM, Amaral IAd, et al. (2004) Equinococose policística na Amazônia oriental brasileira: atualização da casuística. Rev Soc Bras Med Trop 37: 75-83.

26. Santos GB, Soares Mdo C, de FBEM, Rodrigues AL, Siqueira NG, et al. (2012) Mitochondrial and nuclear sequence polymorphisms reveal geographic structuring in Amazonian populations of Echinococcus vogeli (Cestoda: Taeniidae). Int J Parasitol 42: 1115-1118. [Crossref]

27. Li H, Song T, Shao Y, Wen H. Cystic echinococcosis accompanied by hepatocellula carcinoma in a female herdsman. International journal of clinical and experimental medicine. 2015;8(2):2985-8.

28. Reiche EM, Nunes SO, Morimoto HK (2004) Stress, depression, the immune system, and cancer. Lancet Oncol 5: 617-625. [Crossref]

29. Stadelmann B, Spiliotis M, Muller J, Scholl S, Muller N, et al. (2010) Echinococcus multilocularis phosphoglucose isomerase (EmPGI): a glycolytic enzyme involved in metacestode growth and parasite-host cell interactions. Int J Parasitol 40: 1563-1574. [Crossref]

30. Yanagawa T, Funasaka T, Tsutsumi S, Watanabe H, Raz A (2004) Novel roles of the autocrine motility factor/phosphoglucose isomerase in tumor malignancy. Endocr Relat Cancer 11: 749-759. [Crossref]

31. de Almeida FB, Correa CL, de Siqueira NG, de Carvalho NV, Rodrigues-Silva R, et al (2013) Histopathological findings of an uncommon co-infection: Echinococcus vogeli, HIV, hepatitis C virus, and hepatitis B virus. Int J Infect Dis 17: e925-e927. [Crossref]

Copyright: $\odot 2018$ Gonçalves DM. This is an open-access article distributed under the terms of the Creative Commons Attribution License, which permits unrestricted use, distribution, and reproduction in any medium, provided the original author and source are credited. 